\title{
Allergenic pollen: is it also an indoor problem?
}

\author{
Karl-Christian Bergmann · Ludger Klimek · Sascha Nehr · Wolfgang Straff · Barbora Werchan
}

Received: 17 September 2020 / Accepted: 7 December 2020 / Published online: 28 January 2021

(C) The Author(s) 2021

Keywords Pollen · Indoor environment symptoms · Perennial allergy $\cdot$ Perennial symptoms

\section{To the editor}

More than 150 million people in Europe suffer from allergic diseases [1]. Allergic respiratory diseases in the form of allergic rhinoconjunctivitis represent the most common allergic disease, with allergenic pollen representing the main elicitor. Although allergenic pollen is known and recognized as a health problem related to outdoor air, it is not considered an air pollutant in the meaning of the German Federal Immission Control Act, in contrast to airborne substances such as $\mathrm{NO}_{2}$ and fine dust. As such, there is no legal obligation in Germany to measure pollen in outdoor air.

However, in view of the fact that humans spend a large part of their time indoors, indoor pollen levels may also be relevant to health [2,3]. Despite this fact, only a handful of studies are available to date on indoor pollen levels. This "phenomenon" is not pollen-

Prof. Dr. K.-C. Bergmann (凶)

Charité-Universitätsmedizin Berlin, Freie

Universität Berlin, Humboldt-Universität zu Berlin,

Charitéplatz 1, 10117 Berlin, Germany

Berlin Institute of Health, Berlin, Germany

karlchristianbergmann@gmail.com

L. Klimek

Ärzteverband Deutscher Allergologen, Dreieich, Germany

S. Nehr

Europäische Fachhochschule, Brühl, Germany

W. Straff

Umweltbundesamt, Berlin, Germany

B. Werchan

Stiftung Deutscher Polleninformationsdienst, Berlin, Germany specific: if one compares the large number of epidemiological studies on outdoor air pollution with the number of studies on indoor air quality, one notices that, apart from a few notable exceptions, the importance of indoor air quality has been virtually ignored [4]. Few available studies on indoor pollen suggest that various types of pollen-even outside the pollen season-can cause symptoms indoors (e.g., as a result of resuspension) [5]. The concentration of allergenic pollen in indoor air appears to be influenced by multiple factors, such as meteorological conditions, ventilation schemes, as well as the individuals using the rooms [6].

To systematically investigate indoor pollen levels and pollen components, one can draw upon the wealth of experience in the field of pollen monitoring in outdoor air. When focusing on indoor air, the following issues need to be systematically addressed:

- Simultaneous continuous monitoring of pollen concentrations in outdoor and indoor areas of relevant buildings in order to systematically determine the background pollen concentration in model rooms while taking into account buildingspecific and condition-specific parameters. Relatively small, continuously operational, and fully automated pollen counting systems (once their development is complete), for example, would be suitable for this measurement task. The deployment of individual pollen collectors and the use of symptom-focused questionnaires or symptom apps are also considered to be promising methods.

- Conducting systematic studies to differentiate between pollen count and indoor pollen allergen levels, e.g., by investigating indoor PM10 for pollen allergen content.

The systematic investigation of these issues can answer questions on the health-related significance of 
allergenic pollen indoors as well as on specific measures for the reduction of indoor pollen counts.

In the authors' opinion, the scientific investigation of these issues is both helpful and necessary, since merely correlating symptoms of allergic respiratory diseases with the outdoor pollen count is insufficient and can hamper the determination of appropriate protective measures. The detection of relevant indoor pollen levels may explain perennial symptoms in individuals without demonstrable sensitization to the usual indoor allergens (e.g., mites, animal hair, molds).

The aim of this communication is to find co-operation partners with an interest in this topic-please contact Prof. Karl-Christian Bergmann (karlchristianbergmann@gmail.com).

Funding Open Access funding enabled and organized by Projekt DEAL.

Conflict of interest K.-C. Bergmann, L. Klimek, S. Nehr, W. Straff and B. Werchan declare that they have no competing interests.

Open Access This article is licensed under a Creative Commons Attribution 4.0 International License, which permits use, sharing, adaptation, distribution and reproduction in any medium or format, as long as you give appropriate credit to the original author(s) and the source, provide a link to the Creative Commons licence, and indicate if changes were made. The images or other third party material in this article are included in the article's Creative Commons licence, unless indicated otherwise in a credit line to the material. If material is not included in the article's Creative Commons licence and your intended use is not permitted by statutory regulation or exceeds the permitted use, you will need to obtain permission directly from the copyright holder. To view a copy of this licence, visit http://creativecommons.org/licenses/by/4.0/.

\section{References}

1. The European Academy of Allergy and Clinical Immunology. Tackling the allergy crisis in Europe-concerted policy action needed. 2015. www.eaaci.org/documents/EAACI Advocacy_Manifesto.pdf. Accessed 27 Dec 2020.

2. Umweltbundesamt. Richtwerte für die Innenraumluft. 2020. https://www.umweltbundesamt.de/themen/ gesundheit/kommissionen-arbeitsgruppen/ausschussfuer-innenraumrichtwerte-vormals-ad-hoc\#richtwertefur-die-innenraumluft. Accessed 2 Jun 2020.

3. World Health Organization. Burden of disease from the joint effects of household and ambient air pollution for 2016. 2018. https://www.who.int/airpollution/data/AP joint_effect_BoD_results_May2018.pdf?ua=1. Accessed 27 Dec 2020.

4. Nehr S, Hösen E, Tanabe S. Emerging developments in the standardized chemical characterization of indoor air quality. Environ Int. 2017;98:233-7.

5. Korpelainen H, Pietiläinen M. Biodiversity of pollen in indoor air samples as revealed by DNA metabarcoding. Nord J Bot. 2017;35:602-8.

6. Menzel A, Matiu M, Michaelis R, Jochner S. Indoor birch pollen concentrations differ with ventilation scheme, room location, and meteorological factors. Indoor Air. 2017;27:539-50. 